\title{
Sedimentation Study on Upstream Reach of Selected Rivers in Pahang River Basin, Malaysia
}

\author{
Mohd Khairul Amri Kamarudin*, Mohd Ekhwan Toriman ${ }^{\#}$, Noorjima Abd Wahab ${ }^{\#}$, Hafiz Rosli", Frankie \\ Marcus Ata ${ }^{\#}$, Mohd Nazmi Mohd Faudzi ${ }^{\#}$ \\ ${ }^{\#}$ East Coast Environmental Research Institute, Universiti Sultan Zainal Abidin, Gong Badak Campus, 21300 Kuala Nerus, Terengganu, Malaysia \\ E-mail:mkhairulamri@unisza.edu.my,jima_jumaaries@yahoo.com,frankiemarcusata@gmail.com,nazmisyaaban@gmail.com \\ ${ }^{*}$ Faculty of Innovative Design and Technology, Universiti Sultan Zainal Abidin, Gong Badak Campus, 21300 Kuala Nerus, Terengganu, Malaysia \\ ${ }^{\#}$ School of Social, Development and Environmental Studies, Faculty of Social Sciences and Humanities, Universiti Kebangsaan Malaysia, 43600 \\ Bangi, Selangor, Malaysia \\ E-mail: ikhwan@ukm.edu.my
}

${ }^{\#}$ Faculty of Environmental Studies, Universiti Putra Malaysia, 43400 Serdang, Selangor, Malaysia

E-mail: mhafizrosli@gmail.com

\begin{abstract}
The sedimentation study on the upstream reach of Pahang River is located in the Bentong River Basin. The detail hydrographic survey for each river in the Bentong River Basin was carried out in May 2016. Nine stations were selected to represent the sediment concentration at Bentong River, Pahang, Malaysia. Bentong River Basin is one of the river catchment in Pahang River Basin, Malaysia. Before this, Bentong River deterioration in water quality, resulting from the sedimentation problems and unsustainable development management around the river basin. This study was implemented to prove the sedimentation problem, especially the formation of Total Suspended Solid (TSS) in the Bentong River. There are two important parameters were quantified in this study such as the concentration of suspended solid $(\mathrm{mg} / \mathrm{L})$ and the river discharge $(\mathrm{Q})$ values $\left(\mathrm{m}^{3} / \mathrm{s}\right)$. The method used in this study to analysis the concentration of TSS using Gravimetric Method. The result showed the sedimentation in the Bentong River was unstable and the highest of TSS up to 367.6 $\mathrm{mg} / \mathrm{L}$ that is categorized under the class $\mathrm{V}$ which $>300 \mathrm{mg} / \mathrm{L}$ based on the National Water Quality Standard (NWQS) result showed the coefficient correlation between the observed $Q$ and the TSS concentration in the Bentong River is significant $R^{2}=0.919$, there are strong positive relationship between TSS concentration production and the river discharge value in the Bentong River. The study found that the contributors to the high sedimentation problems resulting from the sediments generated from the unsustainable land use, which effectively trapping the bed sediments, rainfall intensity, backflow that carries out high sediments as well as sedimentation produced due to the river bank erosion.
\end{abstract}

Keywords - sedimentation; Bentong River; climate; total suspended solid; river discharge; gravimetric method

\section{INTRODUCTION}

River surface water studies are among the preliminary topics in Malaysia, which provide an overview of the sedimentation problems on the specified river. Sedimentation is a problem that often occurs in the rivers in Malaysia, especially on the main river. Almost $60 \%$ of the rivers in Malaysia are regulated for domestic, farming and agricultural, industrial fields, residential, sewage disposal and urbanization the major pollution sources influencing the river equilibrium in Malaysia [1]. Sedimentation is the process of bringing the material of erosion by water, wind or glaciers [2], [3]. Sediments are a solid material, which moved and deposited in a new location. Sediment consists of rocks and minerals as well as the remains of plants and animals, and all the materials were deposited and will become sediments [4], [5].

Thus, the study was carried out to identify the sediment yield and determine the factors influencing sediment mobility in Bentong River. Processes of erosion, transport, influence sedimentation and deposition and these processes interact along the river to the estuary [6]-[8]. The speed of water flows is the main factor, which affected the capacity to transport the sediment and the sediment movement. So, the processes of deposition of sediment depend on the river discharge and the speed of the river flow [6]-[10]. 
The theory of hydrology described when the higher discharge value and lower the water velocity, the higher amount of sediment load deposited in the downstream area. The action involves the process of erosion, transport, and sedimentation is normal along the river [11]. TSS is a measure of material that is suspended solid on the surface of the water. Most of TSS in the Bentong River is sediment from runoff and bank erosion and makes the water look muddy. The DOE-NWQS rating scale designates $<25 \mathrm{mg} / \mathrm{L}$ as class I, $25-50 \mathrm{mg} / \mathrm{L}$ as class II, $50-150 \mathrm{mg} / \mathrm{L}$ as class III, $150-300 \mathrm{mg} / \mathrm{L}$ as class IV and $>300 \mathrm{mg} / \mathrm{L}$ as class $\mathrm{V}$ [8], [12].

This study also to determine the factors influencing sediment movement. The rivers are very important sources for humans and other organisms as they are needed essential resources for living, especially at the Bentong River [2]-[4], [13]. The sedimentary content and the quality of water were influencing the condition of the river. Then, the frequency and intensity of rainfall in the Bentong River influenced the water level flow and the rates of the erosion process. The positive relationship between the rate of the side and riverbank erosion proposed to increase the sediment production. The velocity of water an important role in the erosion activity and sediment production, the velocity depends on the intensity of rainfall. Generally, the high rate of speed and volume of water, the strong erosion rates [7], [14], [15].

\section{MATERIAL AND METHOD}

The Pahang River is the main river that flows through the state of Pahang, Malaysia. The river begins at the confluence of Jelai and Tembeling rivers in the Titiwangsa Mountains and drains into the South China Sea. At $459 \mathrm{~km}$ in length, it is the longest river on the Peninsula Malaysia. Bentong River is one of the river basins of Pahang River. There are 5 sub basins selected in this study which are Bentong River, Perting River, Chamang River, Repas River and Panjuring River. The extensive human activities such as farming and agricultural, mining, residential, urbanization logging, and industrial have adversely affected to the Pahang River ecosystem (Fig. 1). The sedimentation problems caused the river became more shallow and give a negative impact on the benthic ecosystem and the flora and fauna in the area around this river [16]. The annual increase of suspended sediment load has given bad impact on the drainage system of Pahang River.

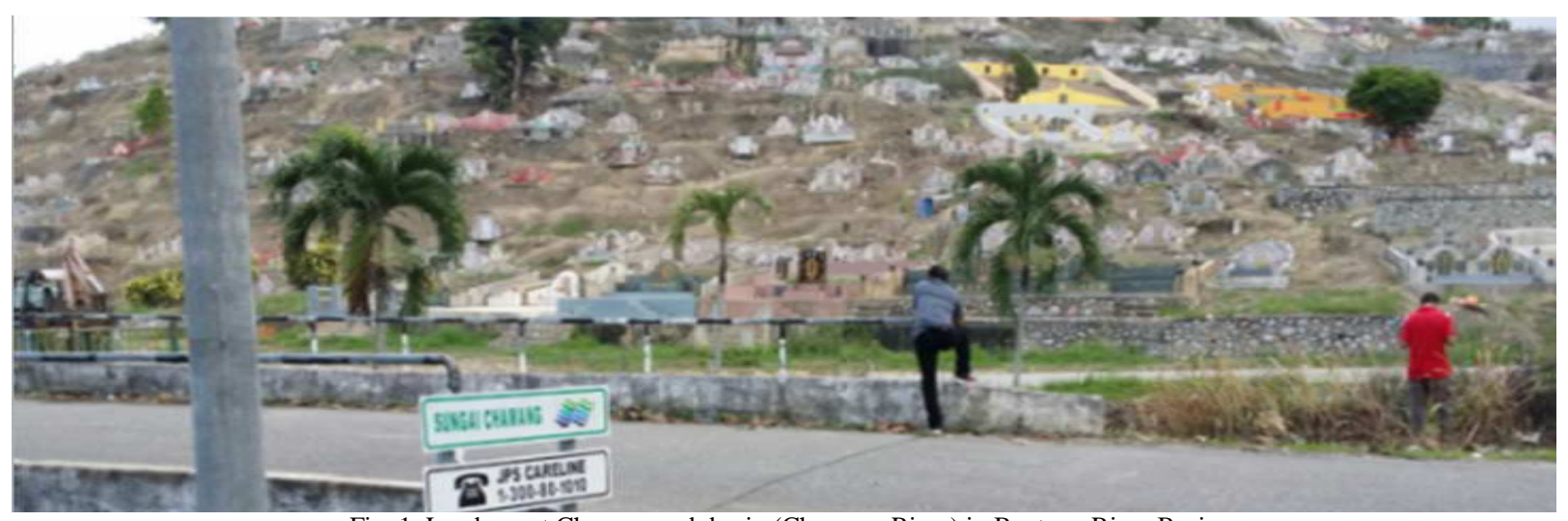

Fig. 1 Land use at Chamang sub basin (Chamang River) in Bentong River Basin

This research is focused on the analysis of sedimentation processes that occur around the Bentong River on the impact of anthropogenic and geomorphology factors such as human activities and hydrological impacts. The movement process of sediment problems one of the factors to the management problems of the river in Malaysia. The primary data and observations during the fieldwork in this research and the results obtained from the fieldwork analysed in the laboratory. 12 sampling stations that have been determined using DGPS were selected (Table 1 and Fig. 2), but the water samples only taken at the 9 stations. It is because of climate problems happened and safety reasons, especially during 'headwater' or 'kepala air' phenomenon.

TABLE I

LOCATION OF SAMPLING STATIONS AT THE BENTONG RIVER

\begin{tabular}{|c|c|c|c|c|}
\hline Sub Basin & River Name & Station & Longitude & Latitiude \\
\hline \multirow[t]{4}{*}{1} & \multirow{4}{*}{$\begin{array}{l}\text { Bentong } \\
\text { River }\end{array}$} & SA1 & $101^{\circ} 54^{\prime} 45.76^{\prime \prime E}$ & $3^{\circ} 31^{\prime} 10.00^{\prime \prime} \mathrm{N}$ \\
\hline & & SA8 & $101^{\circ} 54^{\prime} 6.37^{\prime \prime} \mathrm{E}$ & $3^{\circ} 31^{\prime} 54.27 " \mathrm{~N}$ \\
\hline & & SA8a & $101^{\circ} 53 ' 59.89 " \mathrm{E}$ & $3^{\circ} 32^{\prime} 3.28^{\prime \prime N}$ \\
\hline & & SA11 & $101^{\circ} 52^{\prime} 50.01^{\prime \prime} \mathrm{E}$ & $3^{\circ} 36^{\prime} 45.58^{\prime \prime} \mathrm{N}$ \\
\hline \multirow[t]{5}{*}{2} & \multirow{5}{*}{$\begin{array}{l}\text { Perting } \\
\text { River }\end{array}$} & SA2 & $101^{\circ} 54^{\prime} 26.31^{\prime \prime} \mathrm{E}$ & $3^{\circ} 31^{\prime} 3.82^{\prime \prime} \mathrm{N}$ \\
\hline & & SA3 & $101^{\circ} 52^{\prime} 30.46^{\prime \prime} \mathrm{E}$ & $3^{\circ} 30^{\prime} 35.60^{\prime \prime} \mathrm{N}$ \\
\hline & & SA4 & $101^{\circ} 49^{\prime} 43.33^{\prime \prime E}$ & $3^{\circ} 30^{\prime} 56.89^{\prime \prime} \mathrm{N}$ \\
\hline & & SA5 & $101^{\circ} 49^{\prime} 40.35^{\prime \prime E}$ & $3^{\circ} 30^{\prime} 54.37 " \mathrm{~N}$ \\
\hline & & SA6 & $101^{\circ} 48^{\prime} 54.41^{\prime \prime E}$ & $3^{\circ} 30^{\prime} 3.43^{\prime \prime} \mathrm{N}$ \\
\hline 3 & Chamang River & SA7 & $101^{\circ} 53^{\prime} 55.81^{\prime \prime E}$ & $3^{\circ} 31^{\prime} 39.19^{\prime \prime} \mathrm{N}$ \\
\hline 4 & Repas River & SA9 & $101^{\circ} 53^{\prime} 26.00^{\prime \prime E}$ & $3^{\circ} 32^{\prime} 58.67 " \mathrm{~N}$ \\
\hline 5 & Panjuring River & SA10 & $101^{\circ} 52^{\prime} 46.57 " \mathrm{E}$ & $3^{\circ} 36^{\prime} 47.04^{\prime \prime} \mathrm{N}$ \\
\hline
\end{tabular}




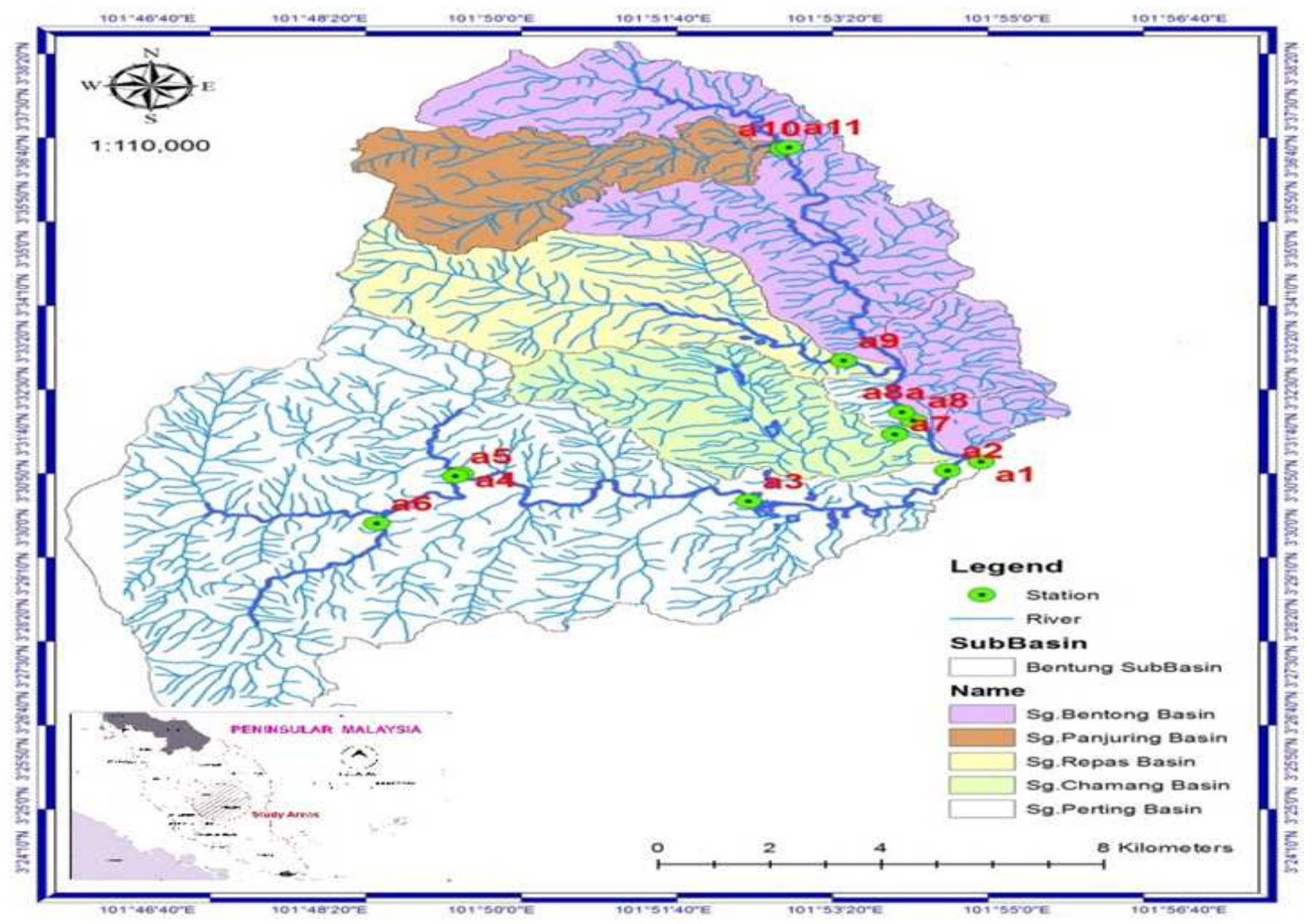

Fig. 2 Location of sampling stations at the Bentong River

The water samples were taken from each station and kept in the $500 \mathrm{ml}$ bottles to find the TSS. The Gravimetric method was used to analysis the TSS measured in $\mathrm{mg} / \mathrm{L}$. In lab analysis, about $250 \mathrm{ml}$ water sample was needed for each study area (each station). TSS measurement was performed by weighing the membrane filter paper $0.45 \mu \mathrm{m}$ one by one and the reading was taken. Firstly, weighing the membrane filters using electronic weighing, then a membrane filter was placed onto a filtration apparatus (Nalgene, U.S.A) which connected to a vacuum pump and clipped in place. The $250 \mathrm{ml}$ river water sample lowly poured into the filtration jar, the membrane filter was removed and allowed to dry in the drying jar. Once the membrane filter paper is dried, it is weighed to get the reading. TSS is measured by $\mathrm{mg} / \mathrm{L}$ unit based on Equation (1). Precisely precaution steps should be taken when the river water sample was taken. Interference of the river water flow should be minimum to avoid deposition of the measured suspended sediment.

$\{$ (weight of membrane filter + dry residure $)$

TSS $=\frac{\text {-weight of mem brane filter }\}(\mathrm{mg}) \times 1000}{\text { Volume of filtered water }(\mathrm{mL})}$

$=\mathrm{mg} \mathrm{L}^{-1} / 1000 / 1000 / 1000$

$=$ tonne $\mathrm{L}^{-1}$
The river cross section and the water velocity (V) for each station were taken using a few hydrological apparatus such as current meter, depth measuring standard, measuring tape and stake. The discharge value $(\mathrm{Q})$ is the product of velocity and cross-section area (A). The cross section area is derived from the product of depth (d) and width (w), the cross section area is trapezium or triangular shaped and the value is half the product referring Equation (2) and (3), which are due to the imprecision of the current meter, variability of the river flow velocity over the cross section and uncertainty in the estimation of the cross section geometry (refer Equation (4) and Fig. 3).

Cross section area $(\mathrm{A})$

$$
\begin{gathered}
A=d w(m) \text { or } A=1 / 2 d w(m) \\
\sum A 1+A 2+A 3+A 4
\end{gathered}
$$

Discharge value (Q)

$$
\begin{gathered}
\mathrm{Q}=\mathrm{vA}, \text { or } \mathrm{Q}=1 / 2 \mathrm{vA} \\
\mathrm{Q}=\mathrm{m}^{3} \mathrm{sec}^{-1}
\end{gathered}
$$

To obtain the unit $\mathrm{L} \mathrm{day}^{-1}$, the following formula is used

$$
\begin{gathered}
\mathrm{Q}=\mathrm{m}^{3} \mathrm{sec}^{-1} \times 86400 \mathrm{sec} \text { day }^{-1} \times 1000 \mathrm{~L} \mathrm{~m}^{-3} \\
=\mathrm{L} \mathrm{day}^{-1}
\end{gathered}
$$




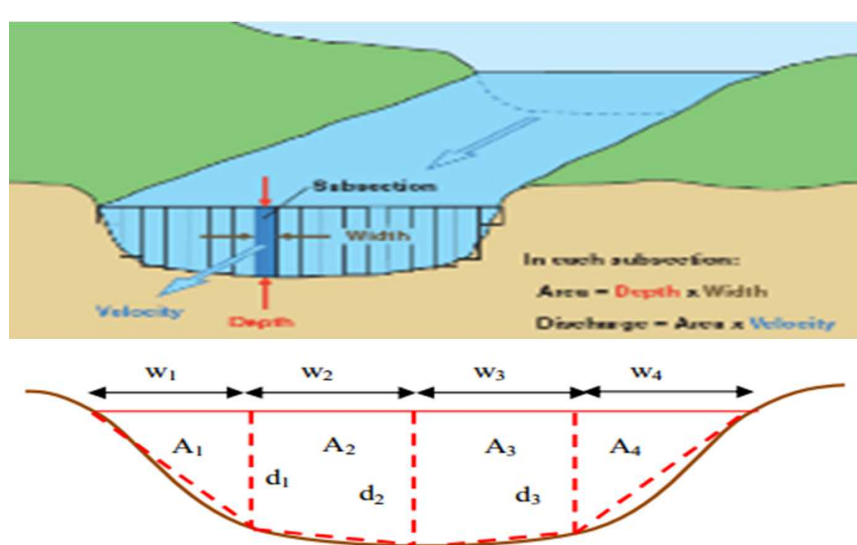

Fig. 3 The theoretical of discharge measurement by cross-section of the river

\section{RESULTS AND DISCUSSION}

The density of water at forest canopy is the main role towards reducing the surface erosion, which contributes to sediment load in Bentong River. When the water flow in a basin increased, the total suspended solid will also increase because the higher flow contains the strong energy to move the higher concentrated the suspended sediment load compared to the low flow. The high water flow also increased the rate of river erosion [17]-[19]. TSS to determine whether the status of water quality clean, moderately polluted or contaminated. TSS is an indicator to classify the river in Class I, II, III, IV or Class V based on the National Water Quality Standard for Malaysia (NWQS) every year [16].

Fig. 4 showed the highest amount of TSS at Station SA3, SA4 (Perting River) and SA8 (Repas River), $367.6 \mathrm{mg} / \mathrm{L}$, $204 \mathrm{mg} / \mathrm{L}$ and $97.2 \mathrm{mg} / \mathrm{L}$ respectively. The minimum level amount of suspended sediment at Station SA7 (Chamang River) is $5.6 \mathrm{mg} / \mathrm{L}$. The result shows the TSS production classified the SA1, SA7, SA9, SA10 and SA11 as class I, SA 2 as class II, SA8 as class III, SA4 as class IV and SA3 as class V. From the result, the difference amount level of TSS at Bentong River affected by the human activities around river basin, rainfall intensity, riverbank erosion and climate changes along the river basin especially at SA3 and SA4 (impact of the 'headwater' or 'kepala air' phenomenon, which occurs around area SA5 and SA6).

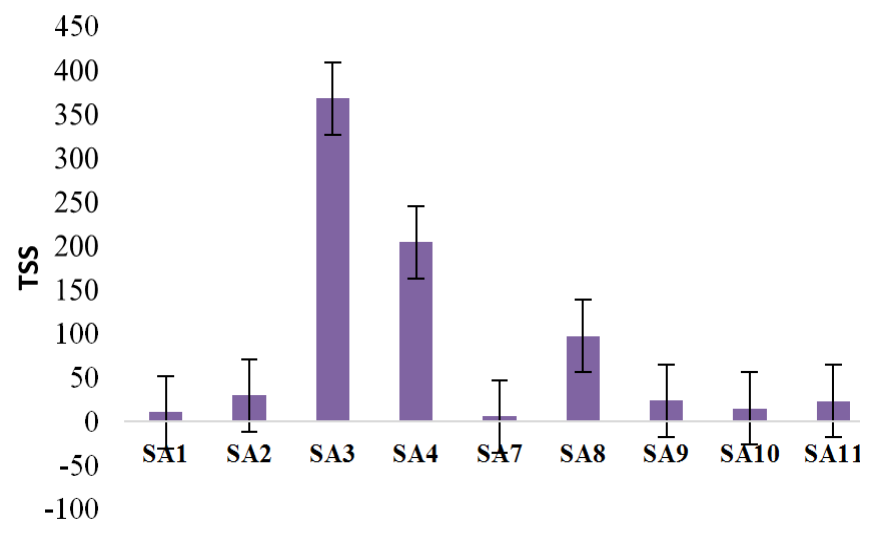

$\mathrm{mg} / \mathrm{L}$

Fig. 4 The Total Suspended Solid (TSS) at the Bentong River
The river discharge value (Q) Bentong River, which includes Sub Basin Perting River, Sub Basin Chamang River, Sub Basin Repas River and Sub Basin Panjuring River. The highest value of discharge value is $6.7877 \mathrm{~m}^{3} / \mathrm{s}$ at Station SA3, which located in the middlestream of basin nearby upstream area. The situation is normal reading for a river, the water velocity in the elevated downstream is lower than the upstream. The impact of 'headwater' or 'kepala air' phenomenon at the SA5 and SA6 caused TSS concentration and discharge value at SA3 and SA4 higher than downstream station (SA8, SA9, SA10 and SA11). The excess water flows out during the heavy rainfall caused the water became very cloudy (Fig. 5). Relatively, there is a natural [26] correlation between the river discharge and TSS, river discharge rate is one of a factor-affected mobility or concentration of TSS, the higher the velocity, the higher the amount of sediment production [20].

Basically, increased the value river discharge will increase the production of total suspended solid and sediment load. However, the frequency and intensity of rainfall, land use activities around the basin, erosion, climate changes and other factors will affect the TSS and sediment load production [21]-[24].

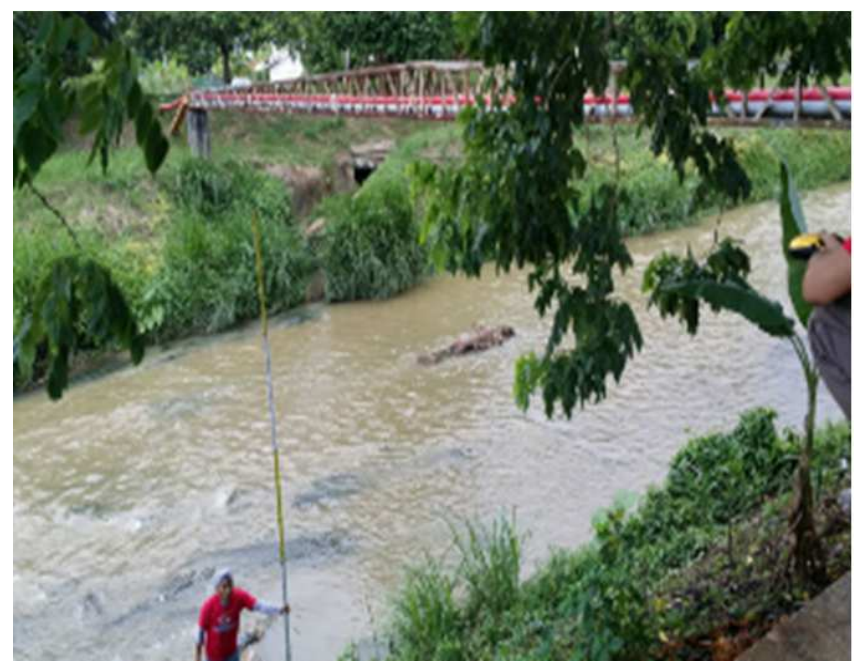

(a)

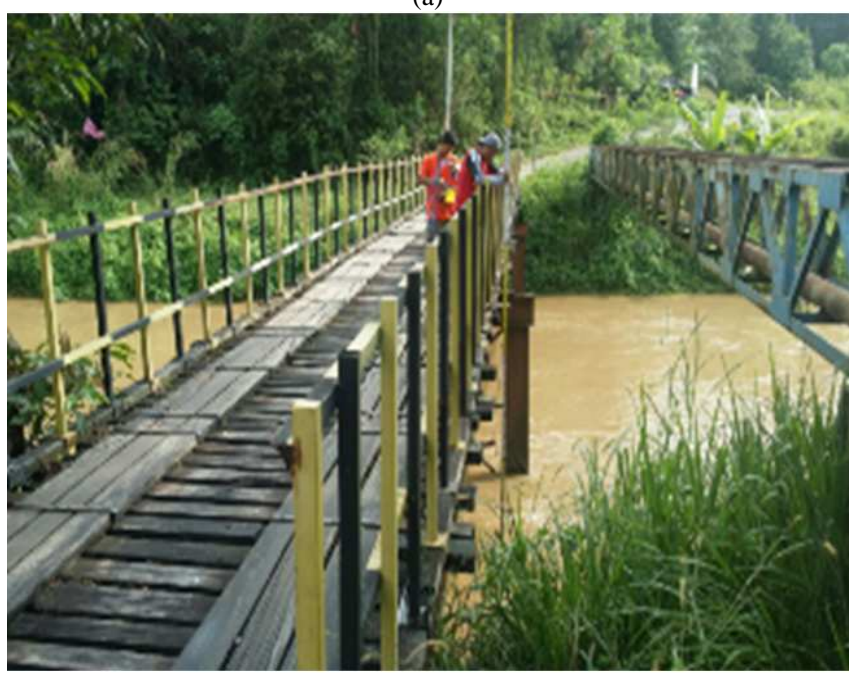

(b)

Fig. 5 a) Before heavy rainfall b) after heavy rainfall (the water became very cloudy) 
There are high significant relations of $\mathrm{R}^{2}=0.919$ shows in Fig. 6. This correlation showed a high positive relationship between Q and TSS. The increase in Q caused an increase in TSS, but this result proved that the $\mathrm{Q}$ was not the main factor to the increased of TSS. From this research, the production of TSS not only depends on the Q but also depends on the others geomorphology factors especially climate factors. Sedimentation is a complex problem in tropical areas as soil erosion due to the very high rainfall contributes to it especially during the unbalance climates happened.

Through the long-term research on changes in suspended sediment concentration load and taking into the weather variable caused by changes in climates. In Table 2, the discharge value $(\mathrm{Q})$ at Station SA3 at the middle stream Bentong River showed the highest value at $6.7877 \mathrm{~m}^{3} / \mathrm{s}$. It is because the data were collected after the heavy rainfall happened. In the normal reading through the hydrological theory, where the discharge value $(\mathrm{Q})$ or water velocity in the elevated upstream is higher than the downstream. The daily suspended sediment yield was calculated to estimate the TSS ton per day. The highest daily suspended sediment load was caused by highest discharge value and the highest suspended yield, the highest value of estimated TSS (tonne/day) or suspended sediment load at Station SA3, 215.5817 tonne/day. For the Station SA2 and SA4, the river discharge data could not be taken because there are some problems to get the data effect by 'headwater' or 'Kepala Air" phenomena (Fig. 7). Other factors also including such as the dumping garbage and waste domestic from domestic activities and urbanization areas.

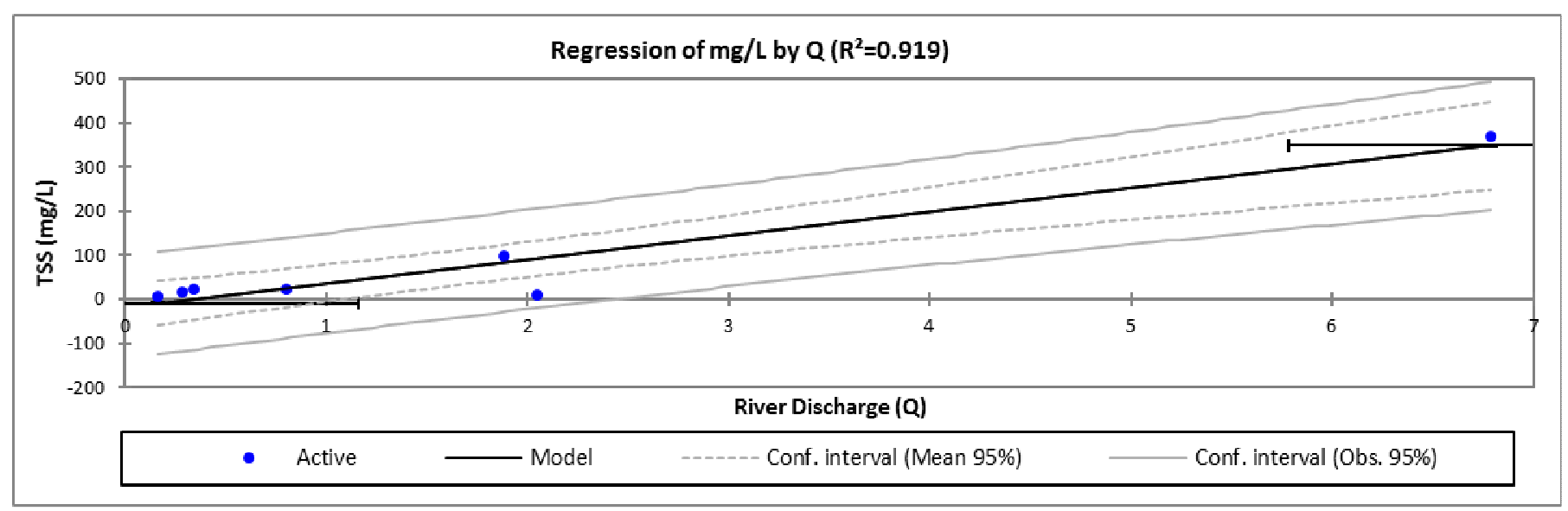

Fig. 6 The Regression of Total Suspended Sediment (TSS) and River Discharge (Q)

TABLE II

ESTIMATED SUSPENDED LOAD IN THE BENTONG RIVER

\begin{tabular}{|l|l|l|l|l|}
\hline Stations & TSS $(\mathbf{m g} / \mathbf{L})$ & $\mathbf{Q}\left(\mathbf{m}^{\mathbf{3}} / \mathbf{s}\right)$ & Estimated Q $(\mathbf{L} /$ day $)$ & Estimated TSS Tonne Per Day (Tonne/Day) \\
\hline SA1 & 10.4 & 2.05175 & $177,271,200$ & 1.84362 \\
\hline SA2 & 29.6 & - & - & - \\
\hline SA3 & 367.6 & 6.7877 & $586,457,280$ & 215.5817 \\
\hline SA4 & 204 & - & - & - \\
\hline SA5 & - & - & - & - \\
\hline SA6 & - & - & - & - \\
\hline SA7 & 5.6 & 0.1617 & $13,970,880$ & 0.0782 \\
\hline SA8a & 97.2 & 1.881 & $162,518,400$ & 15.7968 \\
\hline SA8 & - & - & - & - \\
\hline SA9 & 23.6 & 0.33953 & $29,335,392$ & 0.69232 \\
\hline SA10 & 14.8 & 0.28285 & $24,438,240$ & 0.36169 \\
\hline SA11 & 22.8 & 0.80056 & $69,168,384$ & 1.57704 \\
\hline Average & 86.1778 & 1.75787 & $151,879,968$ & 33.7045 \\
\hline
\end{tabular}
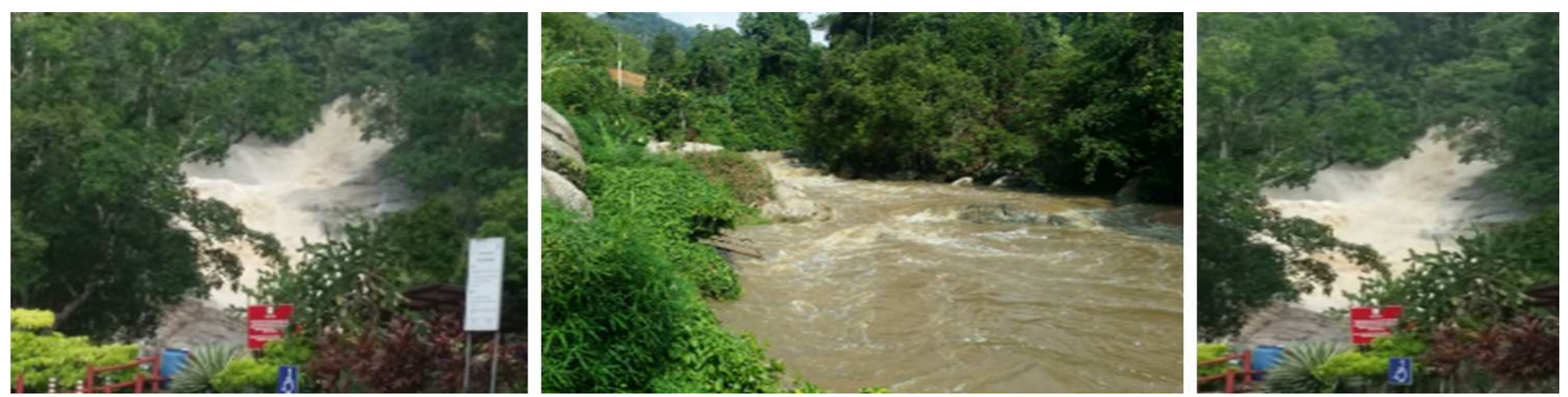

Fig. 7 'Headwater' or 'Kepala Air' phenomena in Station SA5 and SA6 flow out to SA4, SA3, and SA2 


\section{CONCLUSION}

For the overall, the study showed that the suspended sediment yield and the sedimentation problem of Bentong River were stable. From observation during the fieldwork, the sedimentation occurs in Bentong River caused by the land use activities, urbanization and bank erosion along the river basin. Therefore, the prevention and the step towards the need to do with the authorities and the communities as the responsibility for thus environmental issues. This research can be enlightening the public about the importance of the environment, especially rivers. The law enforcement is expected to be carried out, especially to land use activists around Bentong River to preserve and conserve this priceless treasure. Without control of the strategic will disrupt the river ecosystem in the long term and it will give a negative impact on the environment and society. The increasing the sedimentation could lead to increase the turbidity and the odors of water.

The values of river discharge $(\mathrm{Q})$ at the Bentong River are the primary factor that affected the sediment mobility. The increased rate of water flow could cause the suspended sediment yields. The suspended sediment yield was related to the incidence of rainfall that which affected the increasing value of river discharge. From this research proved the sedimentation problem in the Bentong River not only caused by the flow rate of water, but the land use was also contributed to the increasing levels of sediment [25]. Therefore, management and control approach must be thought out and conducted to address these issues before they become more serious as one of the conservation method was suggested to reduce this problem. This suggestion is only based on the scientific study performed by a group of researchers, more thorough and detailed studies about this problem need to be carried out.

\section{ACKNOWLEDGMENT}

This study was supported by the grants from the ministry of higher education Malaysia scholarship under university research grants: unisza/2015/GOT/03 and rags/1/2015/wab05/unisza/02/1. Special thanks are also directed to Department of Irrigation and Drainage Malaysia (DID) for the secondary data and East Coast Environmental Research Institute (ESERI), Universiti Sultan Zainal Abidin (UNISZA) and Universiti Putra Malaysia (UPM) for the helping hand and their contributions.

\section{REFERENCES}

[1] M. K. A. Kamarudin, M. E. Toriman, M. H. Rosli, H. Juahir, N. A. A. Aziz, A. Azid, S. F. M. Zainuddin, and W. N. A. Sulaiman, "Analysis of meander evolution studies on effect from land use and climate change at the upstream reach of the Pahang River, Malaysia," Mitigation and Adaptation Strategies for Global Change, vol. 20, pp. 1319-1334, Dec. 2015.

[2] M. K. A. Kamarudin, M. E. Toriman, M. H. Rosli, H. Juahir, R. Umar, N. H. Sulaiman, F. M. Ata, A. D. Mustafa, M. A. Amran, W. A. Yusoff, and F. Azaman, "Assessment of river plan change using RS and GIS technique," Jurnal Teknologi, vol. 76, pp. 31-38, Aug. 2015.

[3] C. A. L. Jackson, A. A Zakaria, H. D. Johnson, F. Tongkul, and P. D. Crevello, "Sedimentology, stratigraphic occurrence and origin of linked debrites in the West Crocker Formation (Oligo-Miocene),
Sabah, NW Borneo," Marine and Petroleum Geology, vol. 26, pp. 122-134, Dec. 2009.

[4] M. K. A. Kamarudin, M. E.Toriman, S. A. S. Mastura, M. Idris, N. R. Jamil, and M. B. Gasim, "Temporal variability on lowland river sediment properties and yield," American Journal of Environmental Sciences, vol. 5, pp. 657-663, 2009.

[5] M. E. Toriman, M. K. A. Kamarudin, M. H. Idris, N. R Jamil, M. B. Gasim, and N. A. A. Aziz, "Sediment concentration and load analyses at Chini River, Pekan, Pahang Malaysia," Research Journal of Earth Sciences, vol. 1, pp. 43-50, 2009.

[6] S. A. A. Rashid, M. B. Gasim, M. E. Toriman, H. Juahir, M. K. A Kamarudin, A. Azid, and N. A. A. Aziz, "Water quality deterioration of Jinjang River, Kuala Lumpur: Urban risk case water pollution," Arab World Geographer, vol. 16, pp. 349-362, Dec. 2014.

[7] M. K. A. Kamarudin, M. Idris, and M. E. Toriman, "Analysis of Leptobarbus hoevenii in control environment at natural lakes," American Journal of Agricultural and Biological Science, vol. 8: pp. 142-148, 2013.

[8] A. Ismail, M. E. Toriman, H. Juahir, S. M. Zain, N. L. A. Habir, A. Retnam, M. K. A. Kamarudin, R. Umar, and A. Azid, "Spatial assessment and source identification of heavy metals pollution in surface water using several chemometric techniques," Marine Pollution Bulletin, vol. 106, pp. 292-300, May 2016.

[9] A. A. Mohamed, S. A. Rahim, D. A. Aitman, and M. K. A Kamarudin, "Analysis of seasonal soil organic carbon content at Bukit Jeriau Forest, Fraser Hill, Pahang," Malaysian Journal of Analytical Sciences, vol. 20, pp. 452-460, 2016.

[10] M. K. A. Kamarudin, M. E. Toriman, N. H. Sulaiman, F. M. Ata, M. B. Gasim, A. Muhamad, W. A. Yusoff, M. Mokhtar, M. A. Amran, and N. A. A. Aziz," "Classification of tropical river using chemometrics technique: Case study in Pahang River, Malaysia," Malaysian Journal of Analytical Sciences, vol. 19, pp. 1001-1018, 2015.

[11] M. E. Toriman, M. K. A. Kamarudin, T. Sansena, K. Bhaktikuld, R. Umar, A. Muhamad, N. A. A. Aziz, and N. H. Sulaiman, "Assessment of land use change and sedimentation modelling on environmental health in tropical river," Malaysian Journal of Analytical Sciences, vol. 19, pp. 1335-1347, 2015.

[12] A. F. Kamaruddin, M. E. Toriman, H. Juahir, S. M. Zain, M. N. A Rahman, M. K. A. Kamarudin, and A. Azid, "Spatial characterization and identification sources of pollution using multivariate analysis at Terengganu River Basin, Malaysia," Jurnal Teknologi, vol. 77, pp. 269-273, Oct. 2015 .

[13] M. E. Toriman, F.M. Ata, M. K. A. Kamarudin, and M. Idris, "Bedload sediment profile and effect of river bank erosion on river crosssection," American Journal of Agricultural and Biological Sciences, vol. 6, pp. 292-300, Jul. 2013.

[14] A. J. Reading, R. D. Thompson, and A. C. Millington, Humid Tropical Environments, New Jersey, USA: Wiley-Blackwell, 1995.

[15] M. E. Toriman, L. Q. Yun, M. K. A. Kamarudin, N. A. A. Aziz, M. Mokhtar, R. Elfithri, and K. Bhaktiku, "Applying seasonal climate trends to agricultural production in Tanjung Karang, Malaysia," American Journal of Agricultural and Biological Sciences, vol. 9, pp. 119-126, Jan. 2014.

[16] W. A. Yusoff, M. Jaafar, M. K. A. Kamarudin, and M. E. Toriman, "Land exploration study and water quality changes in Tanah Tinggi Lojing, Kelantan, Malaysia," Malaysian Journal of Analytical Sciences, vol. 19, pp. 951-959, 2015.

[17] N. L. Nemerow, Stream, Lake, Estuary, and Ocean Pollution, 2nd ed., New Jersey, USA: John Wiley and Sons, 1991.

[18] F. M. Ata, M. E. Toriman, and M. K. A. Kamarudin," Impact of Interception on infiltration and soil moisture in dipterocarp forest and oil palm plantations in Tasik Chini, Pahang," Malaysian Journal of Analytical Sciences, vol. 19, pp. 1084-1092, 2015.

[19] A. S. M. Saudi, H. Juahir, A. Azid, M. E. Toriman, M. K. A. Kamarudin, M. M. Saudi, A. D. Mustafa, and M. A. Amran, "Flood risk pattern recognition by using environmetric technique: A case study in Langat River Basin,” Jurnal Teknologi, vol. 77, pp. 145-152, Oct. 2015.

[20] M. E. Truman, N. Hashim, M. K. A. Kamarudin, A. J. Hassan, M. B. Gasim, A. Muhamad, and N. A. A. Aziz, "Assessment of water salinity model using hydrodynamic numerical modelling in estuary of Selangor River, Malaysia," Malaysian Journal of Analytical Sciences, vol. 19, pp. 1109-1119, 2015.

[21] C. R. Townsend, The Ecology of Stream and River, London, UK: Edward Arnord (Publisher) Limited, 1980 
[22] X. Zhang and D. E. Walling, "Characterizing land surface erosion from cesium-137 profiles in lake and reservoir sediments," Journal of Environmental Quality, vol. 34, pp. 514-523, Mar. 2005.

[23] A. S. M. Saudi, A. Azida, H. Juahir, M. E. Toriman, M. A. Amran, A. D. Mustafa, F. Azaman, M. K. A. Kamarudin, and M. M. Saudi, "Flood risk pattern recognition using integrated chemometric method and artificial neural network: A case study in the Johor River Basin," Jurnal Teknologi, vol. 74, pp. 159-164, Apr. 2015.

[24] M. B Gasim, M. E. Toriman, M. Idris, P. I. Lun, M. K. A. Kamarudin, N. A. A. Aziz, M. Mokhtar, and S. A. S. Mastura, "River flow conditions and dynamic state analysis of Pahang River," American Journal of Applied Sciences, vol. 10, pp. 42-57, Jan. 2013.
[25] N. A. Wahab, M. K. A. Kamarudin, M. B. Gasim, R. Umar, F. M. Ata, and N. H. Sulaiman, "Assessment of total suspended sediment and bed sediment grains in upstream areas of Lata Berangin, Terengganu," International Journal on Advanced Science, Engineering and Information Technology, vol. 6, pp. 757-763, Oct. 2016.

[26] M. G. Abdullahi, M. K. A. Kamarudin, M. E. Toriman, M. B. Gasim, A. Endut, and I. Garba, "Assessment of natural groundwater recharge in Terengganu, Malaysia," International Journal on Advanced Science, Engineering and Information Technology, vol. 6, pp. 781786, Oct. 2016. 